\title{
Ciberperiodismo en Iberoamérica
}

\author{
Reseña del libro Salaverría, R. (coord.) (2016) \\ Madrid: Fundación Telefónica, Ariel
}

\section{Javier Serrano-Puche ${ }^{1}$}

\section{DOI: 10.5294/pacla.2016.19.4.7}

Para citar este artículo / to reference this article / para citar este artigo

Serrano-Puche, J. (2016). Ciberperiodismo en Iberoamérica. Palabra Clave, 19(4), 11011103. DOI: 10.5294/pacla.2016.19.4.7

Es connatural al ser humano aprovechar los aniversarios y las celebraciones - ya sea de su propia vida, ya sea de las actividades que emprende-, para hacer balance del tiempo transcurrido, ponderando los éxitos y fracasos; tratando, a su vez, de perfilar los desafíos que presenta el futuro. Recién cumplido el vigésimo aniversario del lanzamiento de los primeros medios digitales en Iberoamérica, es un momento propicio para analizar el ciberperiodismo en los países de América Latina, España y Portugal. Ese es el objetivo de este ambicioso libro, "componer el relato de los primeros veinte años (1995-2014) de la prensa digital en veintidós países, separados por un océano y dos hemisferios, pero unidos por sus lenguas y la cultura” (p.xv).

En la obra (editada por Ariel y la Fundación Telefónica —en cuya web se puede descargar de manera gratuita-) han colaborado treinta investigadores, bajo la coordinación de Ramón Salaverría, director del Center for Internet Studies and Digital Life de la Universidad de Navarra. El resultado es un análisis detallado y profundo sobre el nacimiento, la evolución y las tendencias del periodismo digital en cada uno de los veintidós países analizados (para algunos de los cuales constituye, de hecho, la primera investigación académica que aborda los orígenes y el desarrollo de los medios digitales en su territorio).

1 Universidad de Navarra, España. jserrano@unav.es 
El propio Salaverría firma, a modo de marco general, un capítulo que señala los denominadores comunes en toda la región iberoamericana. Pese a los matices que obviamente presenta una zona tan vasta y dispar, cabe apuntar que el avance del ciberperiodismo se ha visto directamente condicionado por el desarrollo de la sociedad de la información y la consiguiente capacidad de acceso a internet por parte de la población. Desde una perspectiva histórica, se puede trazar una evolución en el seno de la profesión, por la cual los medios digitales han pasado de ser acogidos con desinterés, menosprecio y acusados de ser culpables de la crisis económica de la industria de la prensa, a ser hoy reconocidos como actores protagonistas del periodismo en Iberoamérica. Es común entre los países analizados que los medios digitales líderes, ya sea respecto de la audiencia, ya sea del alcance informativo, sean aquellos derivados de los diarios impresos, si bien en los últimos años los medios digitales nativos van ganando terreno y relevancia. Bien como extensiones de una cabecera tradicional, bien nacidos en la propia red, las iniciativas ciberperiodísticas han tenido en estos veinte años de vida fuertes dificultades para consolidar modelos de negocio rentables; lo cual no ha sido óbice para que, en muchos países iberoamericanos, los medios digitales hayan sido un espacio privilegiado donde ejercer la libertad de expresión, superando las presiones políticas y, en ocasiones, la censura que proviene de los Gobiernos y de otros actores sociales. Finalmente, otro elemento común en la muestra estudiada es la ausencia de un perfil profesional claro y sólido en aquellos dedicados al periodismo digital, aunque también en este terreno - con dispar resultado en función de los países y de la envergadura de los medios- cabe detectar avances reseñables.

Una vez expuesto el marco general del Ciberperiodismo en Iberoamérica, el núcleo del libro lo compone el estudio de cada uno de los veintidós mercados nacionales, que aparecen en orden alfabético. Para facilitar el análisis comparativo, todos los capítulos ofrecen una misma estructura. Así, cada uno de ellos se divide en cuatro epígrafes: 1) contexto tecnológico, 2) historia del ciberperiodismo en el país estudiado (en el arco temporal 1995-2014), 3) perfil profesional, formación y marco legal y 4) futuro. Destacan, en conjunto, por la abundancia de tablas y estadísticas, así como por la profusión de capturas de pantalla de los medios digitales iberoameri- 
canos a lo largo de estos decenios, en una suerte de "arqueología de la web" que ilustra la investigación de los autores, por lo demás muy rica en fuentes documentales y personales, algunas de difícil acceso.

La obra se cierra con un epílogo a cargo de Charo Sádaba Chalezquer sobre la innovación en el sector de los medios, cuestión que se proyecta de nuevo de manera transversal sobre los países estudiados. En opinión de Sádaba Chalezquer, los medios iberoamericanos han sabido reaccionar con agilidad a los cambios tecnológicos y de mercado. Sin embargo, la innovación se ha originado más bien en respuesta a esos elementos externos que a una visión estratégica que haga realmente sostenible el cambio. De ahí que parezca claro que los medios digitales "precisan de liderazgo real, y de un auténtico cambio de cultura y creatividad organizativas que les convenza de la necesidad de afrontar cambios, que incluyen no solo ajustes sino también inversión, con el fin de asegurar el presente pero, sobre todo, ganar el futuro" (p. 432).

En definitiva, como bien señala Rosental C. Alves en el prólogo de Ciberperiodismo en Iberoamérica, "en las próximas décadas este libro servirá como referencia obligatoria sobre los orígenes del ciberperiodismo en español y en portugués, así como sobre su situación al cumplir veinte años de edad. Se trata de una sólida contribución a la escasa literatura en esta área de la investigación en comunicación en Iberoamérica” (p. XIII). Con su publicación, por tanto, se colma un vacío en los estudios de periodismo digital y se erige en una obra de consulta ineludible para periodistas, investigadores y estudiantes universitarios de este campo. 
